\title{
Dreamy States and Cosmic Wanderings
}

An Autoethnographic Narrative of Spiritual Experiences in Epilepsy

\begin{abstract}
The medical model attributes religious and spiritual experiences in epilepsy to delusional or hallucinatory events, sometimes diagnosed as a form of ictal psychosis with its causation lying in epileptic symptomatology. Individuals with temporal lobe epilepsy rarely discuss experiences with medical professionals, fearing judgment and pathologization. I problematize understanding these experiences in a strictly biomedical manner. A medical case study is replaced by autoethnographic narrative to describe and analyze spiritual experiences from a nonmedical perspective. This approach emphasizes the phenomenology of the experience and its meaning for the life of the experient. Themes of illness, disclosure, and stigma become transformative. KEYWORDS Epilepsy; Spirituality; Autoethnography; IIIness; Ictal psychosis
\end{abstract}

My lord is fall'n into an epilepsy:

This is his second fit; he had one yesterday...

The lethargy must have his quiet course;

If not, he foams at mouth, and by and by

Breaks out to savage madness.

$\sim$ Othello, 4.I.50-55

In this essay, I focus on my experience of temporal lobe epilepsy and problematize the approach of the medical establishment toward this condition. There is a dearth of first-person accounts of the lived experience of spirituality in epilepsy. Those first-person comments that do exist from individuals with epilepsy who have had spiritual experiences are situated within medical case studies to support an understanding of them as pathological features of temporal lobe epilepsy. Extensive, embodied explorations of the nature of these spiritual experiences are lacking. For example, Bjørn Åsheim Hansen and Eylert Brodtkorb discuss II patients with these "ictal symptoms," but each person is discussed as a medical case study. The result is that there is

Departures in Critical Qualitative Research, Vol. Io, Number I, pp. 50-77. ISSN: 2333-9489, electronic ISSN: 2333-9497 (C) 202I by the Regents of the University of California. All rights reserved. Request permission to photocopy or reproduce article content at the University of California Press's Reprints and Permissions web page, https://online.ucpress.edu/journals/pages/reprintspermissions. DOI: https://doi.org/I0.I525/dcqr.2021.IO.I.5O 
a lack of discussion of the phenomenology from the experients' perspective, or the meaning that the experiences have for these individuals. ${ }^{2}$ In support of this lack of patient-centered phenomenological understanding, the World Psychiatric Association notes in its positional statement in 2016 that there is a need for more research in religious and spiritual experiences in psychiatry $^{3}$; this essay is a response to that call.

Here, I use an autoethnographic narrative to provide an alternative account. I approach the phenomenology of spiritual experiences in epilepsy using the embodied approach of autoethnography. By using autoethnography, I extend a hand to the reader to join me in societal misunderstanding. I contend that society has formalized, through neuropsychiatric medicine, a way of rejecting individuals with epilepsy and their experiences in favor of symptomatology and diagnosis. As a condition that affects the whole body as well as the mind, epilepsy is a truly embodied experience.

My experience is understood using a lens of spirituality and a respect for mystical experiences. I propose here that by clinging to scientific materialism, the medical establishment lacks respect for spiritual experiences in epilepsy, denying those with epilepsy the right to have them, and instead forcing a spoiled social identity and status of sickness over all other aspects of life. Sickness becomes the identifying feature of those with a chronic illness. ${ }^{4}$ Here, I reject the status of a passive sufferer of illness, to be pitied. Instead, I adopt the non-pathologizing term "experient" (meaning "one who experiences”) from psychological literature. In this essay, I refer to all such spiritual experiences as epileptiform events (EFEs). I propose this as a more neutral description than the medically oriented terms "seizure" and "aura," the colloquial term "fit," or the more judgmental term "outburst." I identify a tension that exists between the medical understanding of these experiences and the meaning typically attributed to them by those who have them. This tension is worthy of deeper consideration because society silences those who experience it in favor of medical diagnosis.

\section{TEMPORAL LOBE EPILEPSY AND SPIRITUALITY}

Epilepsy is one of the oldest and most common neurological conditions, affecting 50 million individuals globally. ${ }^{6}$ Epilepsy is identified as an enduring tendency to have recurrent seizures. ${ }^{7}$ It is a spectrum disorder, with at least 40 variations that have different symptoms and causes. ${ }^{8}$ It is common for people to experience multiple types of seizure, ranging in severity from 
infrequent momentary absences to, at the most extreme, sudden seizurerelated death. ${ }^{9}$ Rajendra Kale states that the history of epilepsy is "40oo years of ignorance, superstition and stigma followed by roo years of knowledge, superstition, and stigma." ${ }^{10}$ Despite increased medical understanding of the condition, public perception and treatment of those with epilepsy continues to be poor, and it remains "a stigmatizing condition par excellence."11 The World Health Organization notes that individuals with epilepsy often avoid engagement with treatment for their symptoms because they find the social stigma and prejudice more difficult to engage with than their seizures. ${ }^{12}$

Temporal lobe epilepsy is the most common form of epilepsy. It is characterized by seizures originating in the temporal lobes, involving a short period of impaired consciousness. ${ }^{13}$ Some individuals with the condition have feelings and sensations associated with a state of consciousness that is qualitatively different from anything they have in their normal waking state. ${ }^{14}$ Termed "auras," ${ }^{15}$ they are described by those who have them in terms of their ineffable and numinous quality ${ }^{16}$ including déjà-vu, jamais-vu, out-ofbody experiences, and felt presences, with mystical, cosmic spirituality, and ecstatic feelings. ${ }^{17}$ For those who experience them, they often have spiritual connotations. The medical establishment would pathologize them as sufferers. Kenneth Dewhurst and A. W. Beard reported six cases of individuals with epilepsy who underwent "sudden religious conversion," ${ }^{18}$ and Fabienne Picard and Andrew D. Craig interviewed five people, whose experiences included no longer fearing death, seeing the world in a different way, and having a deep sense of joy and harmony with the universe. ${ }^{19}$ Fyodor Dostoyevsky recounted feeling "such a happiness that it is impossible to realize at other times, and other people cannot imagine it... a complete harmony within myself and in the world. ${ }^{20}$ Hildegard von Bingen composed music in the I 2 th century that would now be termed mystical, yet in relation to her supposed epilepsy is deemed ecstatic - that is, a mere symptom.

From the biomedical perspective, these experiences are interpreted as symptomatic of either an epileptic or psychiatric disorder. ${ }^{21}$ They are regarded as individually and culturally unlike usual, ordinary, or expected experiences. ${ }^{22}$ As such, they are deemed neither authentic nor appropriate to the hegemony of neurotypical functioning, and the conventional reaction of the medical profession to an individual reporting such an experience is to pathologize it, ${ }^{23}$ regarding it as, at best, delusional or hallucinatory ${ }^{24}$ and, at worst, symptomatic of Geschwind syndrome, a contested behavioral diagnosis still used by clinicians. ${ }^{25}$ It is identified by hypergraphia, an intense mental 
life, hyposexuality, irritability, and hyper-religiosity. ${ }^{26}$ William James found this materialist understanding of EFEs to be too reductive. ${ }^{27}$ This is supported by epileptologist Peter Fenwick, who notes that such reductionism demands neurocognitive accounts of all experience, when no such thing is yet possible. ${ }^{28}$ Jacob Kaminker and David Lukoff question the judgment of stigmatizing non-ordinary experiences that sit outside a shared, consensual reality. ${ }^{29}$ This is particularly pertinent when cross-cultural attitudes are considered; for example, there are notable historical and contemporary accounts of shamans with epilepsy, for whom such experiences are highly valued. ${ }^{30}$ Oliver Sacks has highlighted that these experiences may be like our aesthetic sensibility, and that a strictly biomedical perspective offers little insight into the significance and the meaning that they have in individuals' lives. ${ }^{31}$

\section{Diary Entry: May 2019}

Reflecting upon my own epilepsy, I realise that as well as being stigmatized, I am also medicalised. I am not "an epileptic" and I refuse to be defined by an illness. What to be called, then? In an effort to avoid this, the medical establishment has created an abbreviation that is supposedly less offensive: PWE-people with epilepsy. The result? Removal of status as a fully functioning human being that fits into usual society; a reduction to a condition carrier, a collection of unwanted and unpleasant symptoms that do not have a place within "nice" society. When I first began reading papers about epilepsy, about me, I kept coming across the words PWE. PWE were morelless responsive; PWE and issues with...Ah, I see. People with epilepsy. We don't even get a name now; outsiders, reduced to a neat abbreviation.

\section{EFFING THE INEFFABLE: FINDING A WAY TO LET PEOPLE IN}

With its focus on heartfelt embodied personal experience, and its layered, non-linear approach, autoethnography is a highly appropriate methodology for considering non-linear or misunderstood unusual experiences not accepted within the norm that EFEs represent. ${ }^{32}$ Autoethnography has previously been used to problematize reactions to misunderstood and stigmatized mental and chronic illness, illness in ageing, and some aspects of the experience of having epilepsy. ${ }^{33}$ Using an evocative autoethnographic approach, I applied Heewon Chang's evaluative questions (based on 
trustworthiness of data; reliability transparency; ethical considerations; analysis and interpretation of sociocultural meaning; scholarly contribution) to ensure an effective and rigorous narrative. ${ }^{34}$

The process for this research started by identifying autobiographical material providing authentic and trustworthy data. Diary entries, pictures, poetry, and reflective prose were collated, and a time period that would be sufficient to provide a "thick" description of the nature of my experience was chosen. A chronological sequence was devised from the data to create an engaging narrative for the reader that was also evocative of my experience. ${ }^{35}$

The artist David Hockney commented that evocative paintings are a composite from memory and emotion, ${ }^{36}$ and I suggest that autoethnography is the same. Following Nigel P. Short, I have approached the presentation of the autoethnographer's data in an embodied manner, whereby I present my memories as trustworthy accounts. ${ }^{37}$ However, by including my reflexive account, this has both exposed my emotional response to public scrutiny and offered me a new way of understanding the nature of those events themselves. ${ }^{38}$

I was aware of the need for ethical sensitivity for everyone implicated in the research ${ }^{39}$ and used Martin Tolich's ten ethical considerations as a basis for considering this. ${ }^{40}$ The autoethnographic material presented here has been carefully evaluated with regard to risk to the researcher, while simultaneously acknowledging that sharing such deeply personal writing is an uncomfortable but necessary feature of the approach. ${ }^{41}$ As a psychotherapist, I have drawn on my critical reflexive practice to embody my subjective experience as a primary element of the research. ${ }^{42}$ Autoethnography has offered me a way to connect, through this narrative, the deep, and not necessarily comfortable, relationship between my personal experience of epilepsy and the sociocultural context I mirror. ${ }^{43}$ Where appropriate, pseudonyms have been used. I have chosen not to use a pseudonym for myself. Photographs have been cropped to remove the faces of individuals I am no longer in contact with, and all identifying features of consultants and hospital appointments have been obscured.

As I and my experience are the data, ${ }^{44}$ so too are the culture that I am situated within and reflect through my narrative inextricable elements of the research. By aiming to understand EFEs within the cultural context they are lived through, this autoethnography emphasizes the use of personal experience to examine not only the self, but also wider sociocultural responses to a specific issue. ${ }^{45}$ The intention is for the reader to consider their own 
response to the material and how this reflects sociocultural aspects of the narrative and its intimate personal presentation, perhaps offering a new lens of engagement. ${ }^{46}$

A key feature of this narrative is its form. The approach I have employed is intended to subvert the usual manner in which epileptic events are discussed in the neuropsychiatric literature. I have used a case study format from epilepsy patient reviews. ${ }^{47}$ Such reviews collect data from the perspective of the medical professional-gathering patient history, commenting on investigations, including MRI and other tests-and end with an assessment and diagnosis made by the professional. The patient's experience is only included insofar as the medical professional judges it relevant. The judgment of what is and is not relevant is decided in light of the diagnosis. In this essay, I have inserted autoethnographical material in each of the case study sections as a deliberate contrast to the medical terminology and diagnostic criteria ordinarily constituting these reviews. I judged the material inserted on the basis of how much it brings my narrative to the fore. Neurological, psychiatric, and psychological lenses are tied to personal experiences to act as mirrors to society. In doing this, I have problematized the ways EFEs are usually presented and understood.

\section{CLINICAL HISTORY}

Figures I and 2 are photographs of me just before and after my diagnosis of epilepsy. I include them here, at the start of my narrative, as I have chosen them as artifacts that take me back to the start of my journey with epilepsy, evoking my emotional response at that time.

I was diagnosed with epilepsy at age I8, in the middle of my "gap year" between high school and university. Living abroad, I had been found on more than one occasion unconscious in the front gardens of the people I lived with. They thought that I had fallen, drunk; that I was irresponsible and selfish. The first time it happened, I slept for four days straight. I had a relentless headache that was so painful it hurt to move my head, and my limbs ached. After the third or fourth time, I was hurting myself badly; there were bumps, cuts, and a bloody face. No one wanted to talk about it, and they certainly didn't want me living with them. I was sent home for investigations.

I felt rejected and punished and these feelings then transformed into a deep sense of anger that I did not know how to engage with. Scans and tests followed, culminating in a diagnosis of epilepsy and medication. I felt 


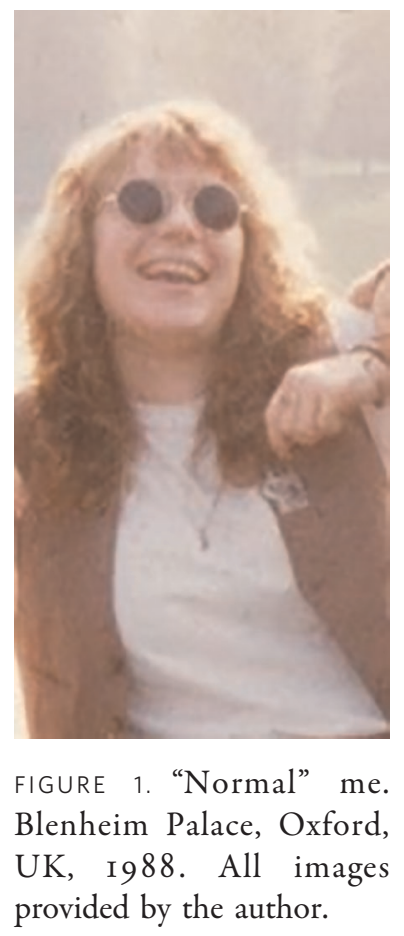

bemused. Like many with no freely available information, my parents' response to my diagnosis was a protective one, but unfortunately this led them to see it as a burden I would have to carry. With a lack of support from medical professionals and a fear for my welfare, they responded as many parents do to a diagnosis of a child with epilepsy, with sadness and chronic sorrow. ${ }^{48}$ In my emotional immaturity, I found my parents' concern distressing, and pushed them away in anger, increasing their worry and making it harder for them to in turn support me.

Around this time, the Alton Bill was being debated in the United Kingdom, a private member's bill intended to restrict the period during which abortions were legal from 28 to I 8 weeks, potentially leaving women without the choice of whether to abort children with birth defects. ${ }^{49}$ No one seemed to care about anything but my compliance to medication. I noted from the side effects accompanying my tablets that women who take medication for epilepsy have a higher risk of fetal abnormalities that include cleft lips and palates, congenital heart defects, malformations of the face and slow development. ${ }^{50}$ I listened to punk songs like "Smash Clause 28 !"51 and became a protester. I shouted at people. My rage had found an outlet. Figure 2 


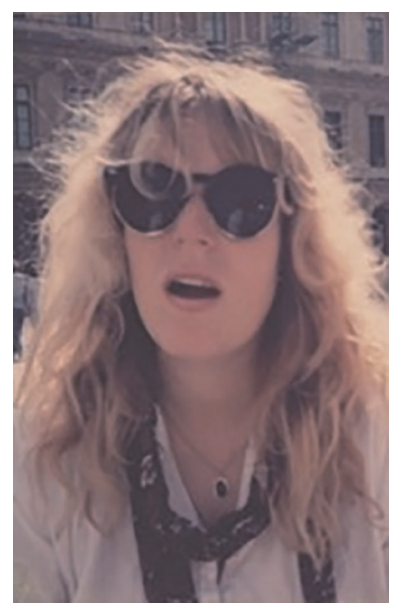

FIgURe 2. "Abnormal" me.

Louvre, Paris, France, 1989.

reminds me of how hot and reactive my fury was-and how vulnerable my response left me. That holiday in Paris was cut short because I wasn't taking my medication.

I look around a room. I don't know where I am. Desperately, I try to remember this place. Should I know it? Who am I with? What day is it?

"Where am I?" I groggily stammer.

The pillows feel soft beneath me, as if I am resting on deep, fluffy, welcoming clouds. I feel the crisp bedlinen, cool against my aching limbs and look up as the weak, pale late-afternoon light filters lazily through a flimsy pair of inadequately drawn curtains.

"Don't worry, I am here," a comforting voice says, and I look up to see a face, too close, too real, too bright.

I know this voice but I am not sure how. Panic sets in. Do I know the face? My head screams in sharp bursts of pain, stabbing at my temples and screeching across my head. I want to give myself over to the pull of sleep, but I need to know what is happening, to be sure I am safe. The eyes are soft and brown and a gentle touch is stroking my forehead. I feel confused. I cry, overwhelmed with waves of sadness I cannot control. I close my eyes and sink into the bed as arms reach out to rock me back to sleep.

Hours later, I wake to see him sitting, reading quietly by my bedside.

"You're awake, how do you feel?" he asks tenderly.

"Groggy" 
"I think we need to get you home; we've been here a day already."

The thought of moving is too much. I turn over and go back to sleep.

I am woken by the urgent need of my bladder. The sun is shining brightly through the numerous gaps in the curtains, the world is going about its noisy business, but I am alone. For a moment, I don't remember. And then it descends, the knowledge of what may have happened. The pain returns and my head is agony again. I groan. I feel I need to be away from this place, from the humiliation of whatever has transpired. I move, sloth-like, packing my possessions. I didn't really get to unpack them. We need to buy plane tickets. I pull everything out of my purse, looking for the necessary traveller's cheques. I am methodical in my planning. I saved these cheques, wouldn't cash them on the wild trip we had. I was sure to guarantee we had more than enough to cover the journey home. The purse is empty. I know we had a slim sheaf of them. I begin to wonder if I have carelessly lost them somehow.

"Well, good morning," he says as he steps through the door, moving over to kiss my forehead. I finch at the sensitivity of touch and as I do, see the rejection pass across his face.

"I can't find the traveller's cheques, they've gone," I say in a monotone, trying to keep the pain at bay, minimal movement, minimal sound, hoping he won't raise his voice because that, too, will hurt. It's no use, he can't.

"What do you mean?" The exasperation is palpable, two days of patiently nursing collapses in a frustrated wail.

"They're not there, we can't get home."

I haven't the energy to walk to the reception. He goes instead. The manager has denied all knowledge of the cheques going missing. We are stranded in Paris with no money. I can't cope with this; my head is banging, and all I want to do is to sleep, to be at home, in familiar surroundings. I feel frantic, but I give in and collapse into sleep, I just can't do this.

When I wake, he has been on the phone to the police. They have been here, moving around the room, looking through my things as I sleep. I'm disoriented and I feel invaded.

"What day is it?" I ask.

"It's Wednesday. You've been asleep for two days. We need to go home. We can't do this here. I have made arrangements and we need to go."

I pack in silence and we go out into the vibrancy of Paris for breakfast. I feel unsteady and uncertain my legs will hold me up. A pain is present in my legs. No one warns you about this, but I have learnt that this pain is the result of the rigid spasms of my limbs during my seizures. I only know I have had a seizure because 
this pain is present-a sharp ache on the inside of my thighs. The pavement is hard under my feet, and I lean on his arm as he leads me to a seat. Everything is too much - too fast, too hot, too bright, too colourful, too loud, too sweet. My mouth is full of ulcers and my tongue is so thick it fills my mouth; every sip and chew a fresh wave of agony.

We slowly climb the antiquated wooden stairs; leaning on the wobbly balustrade feels precarious, reminding me that my solid, stable body hasn't returned yet and I am as an old woman-shuffing, overwhelmed by the world.

\section{General History}

In the autumn of 2012, the breakdown of my marriage forced me into extreme levels of stress and emotional vulnerability. I began to question my sense of selfidentity, and unravel emotionally and psychologically, the condition that I had always rejected became a serious concern. I experienced uncontrolled and damaging seizures-a shock as I had not suffered them for over two decades. I never embraced my condition, but I took the tablets. I didn't tell people about it. It was a secret I chose mostly not to disclose. People didn't know unless something went wrong. Now, I was fearful that they would not stop. In an attempt to stabilize my condition, I requested an appointment with a neurologist.

I have always hidden my epilepsy. When I began to have EFEs, I hid them even more. This autoethnography is a choice to deliberately disclose the stigma of EFEs and draw attention to an otherwise invisible taboo. I know it is a feature of my condition that others will find difficult to understand outside a "safe" medical context-and I accept the vulnerability of doing so. The status of epilepsy as a so-called "invisible" disability is ambiguous and complex. ${ }^{52}$ Individuals ignore their condition or hope it will subside, ${ }^{53}$ and with adolescents this may suggest an internalized desire to be neuronormative. Individuals frequently choose to conceal, or not disclose, their condition, and exposure is likened to coming out of a revolving closet, where some are told and others not. ${ }^{54}$ Malcom Hayden, Carolyn Penna, and Neil Buchanan found that 52 percent of their survey respondents would not disclose their condition to acquaintances, 21.5 percent would not tell close friends, and 13.6 percent would not tell anyone at all..$^{55}$ It is likened to "com[ing] out from [the] closet."

\section{Examination}

Diary Entry: July 2014 
"The consultant is very late, I am so sorry," says the secretary. "He is fying in, you see." I look up from my hands. I realise that I have not been listening, that I have been wandering for an hour, lost in the dreamy world of what-ifs and howcans. "Would you mind if his registrar saw you instead?" I take no time to consider and chirp out, "Oh no, that's fine" brightly, not knowing whether or not this will be of any use. I haven't been here for many years and the return is not a welcome one. I start the conversation; I know what I want-I need an MRI scan. So, I tell the young (very young, it seems) woman. We talk about my research. It is too scary to talk about my own experiences. "So, why are you here?" says the perky young doctor. It takes my breath away. You have to do this, I remember, trying to be calm, not to lose composure. "I have had seizures, out of the blue." I know the next question so quickly add, "I am fully compliant with my medication." Big, fat, soft tears begin to drop from my eyes, the room is swimming, I can't talk.

Slowly and gently, I talk about my situation, about the seizures, my fear, the need to explore what is happening. And then, surprising myself, I admit the experience I have been having for years, the details that I haven't told anyone, because I feared they would say this was something very, very, bad. "I leave my body, I go into the cosmos, I can see the earth from the stars," I blurt out. The neurologist looks lost; I feel that she wants to do something but seems to be embarrassed by what I am saying, and professionally out of her depth. I feel that she can't engage with my fear and the cheeriness has gone. She says, "I think you need a scan."

Although EFEs vary, accounts often include a sense of accessing a joyful and harmonious ${ }^{57}$ non-shared reality ${ }^{58}$ unlike anything else experienced, ${ }^{59}$ which medical professionals find difficult to engage with except as a symptom. One woman explained their transformative nature by saying: "It is a big happening in your life to have these seizures. Thanks to these experiences, I do not fear death anymore. I see the world differently." ${ }^{60}$ Elizabeth Barrett Browning understood the nature of this mystical type of seeing in Aurora Leigh: "With eyes immortal, to the antetype / Some call the ideal,--better call the real." ${ }^{\text {"61 }}$ Descriptions and experiences of EFEs share a phenomenological similarity with other nonnormal, or anomalous, experiences. ${ }^{62}$ Anomalous experiences are defined as those that "depart from our own familiar personal experiences or from the more usual, ordinary, and expected experiences of a given culture and time." ${ }^{63}$ In non-epileptic populations, they are seen as irrational or pathological and are regarded by some as dangerous, or even "an abomination." 64 Elizabeth C. Roxburgh and Rachel E. Evenden observe that individuals fear 
mentioning anomalous experiences as they expect to be labeled as mentally ill. ${ }^{65}$ It is hardly surprising, therefore, that individuals with EFEs are reticent to discuss them, or keep them secret for fear of judgment. ${ }^{66}$

\section{Special Studies}

Diary Entry: Sept. 2013

I am sitting in a business meeting with my manager. I am telling her about the work I am doing currently. It is a normal day. We are discussing nothing special. In the space of a moment, there is a lurching feeling in my stomach, as if my organs are dropping from an ordered place to the bottom of my body. The sensation is of being woozy and needing to be sick. I feel my mind move. It is as if it tips to the back of my head. I try to grab onto it, to keep hold of it. But I have slipped away. I have to sit back. I need to take a deep breath, to ground myself. My mouth produces saliva, I have the need to swallow, but no ability. A fear ominously rises from the pit of my stomach. "I know you, old friend," I think. I look around me-the colours are brighter, sounds are louder, there is a quality of the unreal about the everyday. It feels too much. I feel sad, very sad. Everything is carrying on as normal, but I am not. I feel my body transported a long, long way away. I am in the outer cosmic regions of space, looking down on the earth. It is blue and covered with clouds that swirl and move over its surface. The tiny ants of humanity move over its surface, moving fast, going nowhere. I sit among the planets. Darkness abounds. No sounds, no smells. But I know how it is connected. I know how the universe works. And I feel calm, at peace.

EFEs are largely dismissed as merely symptomatic of the condition ${ }^{67}$ and professionals dismiss patient worries and concerns as exaggerated. ${ }^{68}$ Psychiatrists see EFEs as ictal (epilepsy related) psychosis. ${ }^{69}$ Robin Wooffitt highlights how individuals who have anomalous experiences position themselves as skeptical of the "paranormal" to pre-empt expected challenges to the validity of their experiences. ${ }^{70}$ Even the most sympathetic members of the medical establishment comment on how these experiences manifest as psychotic symptoms. ${ }^{71}$

\section{Neuropsychological Assessment}

My epilepsy is unpredictable, generally completely absent. While some individuals have a warning, or aura, the seemingly erratic nature of seizures, even with mostly effective medication, can be a distressing feature of the condition. ${ }^{72}$ Rita Charon reminds us that the act of narrative telling is a vital aspect of coming to 
terms with one's illness; the narrative itself is an essential feature of establishing its meaning to self. ${ }^{73}$ I have found that healthcare professionals' attitude toward EFEs is to shut down that telling, by judging the nature of my experience as pathological. This "epistemic injustice" 74 is distressing, isolating; it leaves me unable to be understood by those who are charged with my care, and negates my own understanding of my illness. Havi Carel offers a framework with which to see illness as a transformative experience. ${ }^{75}$ By accepting the validity of my EFEs, I can understand them as an essential part of my spiritual journey; that they hold within them the opportunity for growth. This narrative is an act of spiritual discovery and transformation.

Diary Entry: 2I July 2015 (see Figure 3)

Working with my therapist, I re-enter a dream I had on the night of the solstice. In my dream, I saw three identical men with long, flowing robes and grey beards. They looked like Rabindranath Tagore, one of my favourite poets and a man of great spirituality and wisdom. I knew he was offering me choices between things of great value. Having explored the first and second purse, I moved to the third purse-it was empty. I tipped it upside down. Nothing. I looked inside, had I missed something? A solitary grain of sand, and then a pouring, more and more. The dune seemed to grow-soon a sand dune stretched into the horizon. I was hot, the sun beat on me and the dune was scorching my feet. But the dune kept pouring, like some mysterious magic trick. Surveying the landscape, I saw a featureless sea of sand, the only difference was ripples along the side of the constantly growing dune. Sand stretched forever. As I looked ahead, I felt the sand beneath me shift and circle, I was being pulled downward. The pull of the sand was as if someone had pulled an enormous plug and I was being sucked down a huge drain. There was incredible movement and a force all of its own. I felt suffocated, my chest was restricted, my breathing fast and shallow. It was frightening, dark, fast. The pull kept going for a long, long time. I kept falling. A nausea rose in my throat. Then, suddenly, I was at the bottom of a long, dark well. Looking up, I saw a single star shining in the blackness of the sky above. As my focus shifted to the star above me, I began to physically disintegrate, there was no "me." I was becoming a clear jelly fluid, losing myself. It coated the bottom of the well and began to seep into the ground, to disperse. The fuid had no coherence or consistency; it had become single molecules mixed with the earth, with the light of the star shining upon it. My awareness was of connectedness, calm; the unity of consciousness. And with that feeling of unity, I knew that I had to return to the light of the star, that this was the source of spiritual importance. 


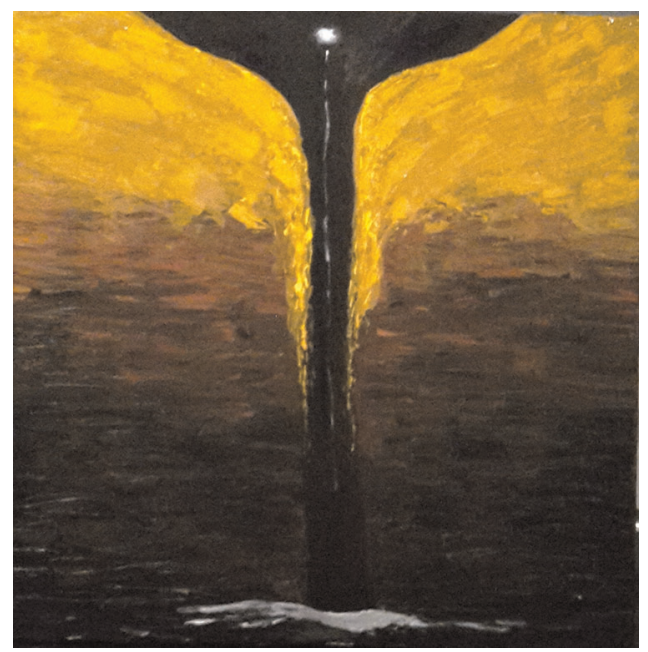

FIgURE 3. The Shifting Sand. My painting in acrylic and gold leaf, August 2015.

I was beguiled by the light of the star, it seemed to fill the sky and I felt drawn to merge with it, to become one. I imagined stretching my arm out to feel it clothe my skin. My therapist invited me to enter its consciousness. As I tried to do this, it was a very, very comfortable feeling, like slipping into a warm bath. And in that moment, I knew I was at one with the consciousness of the universe. It whirled like a typhoon inside, and I felt myself whisked around like a rag doll. The energy inside the consciousness of the star was powerful, primal. Having my mind connected to it was at first the calmest, most beautiful experience I had ever had. This seemed like my heart's home, the source of all belonging. I laughed in delight.

And then suddenly, it became a most unpleasant feeling, unbearable almost, and I wanted to scramble out, claustrophobic, suddenly. The light was pure energy, but I had regained my own consciousness and ego again, and in doing this I couldn't meld with the star and it was too much to bear. As soon as I had separated myself from the energy, the star spat me out with huge force. In the session, I was breathless, taken aback by the strength of the experience. This dream was transformational, it helped me to see that my epilepsy connects me with my spirituality. 
Closing my eyes now, I can re-enter the star's consciousness and I realize that the feelings of disorientation and suffocation are just like those I feel as I have a seizure. And the beautiful calm, the sweetness-that is the cosmic ecstasy that I touch, all too briefly. My seizures connect me with the energy that runs through, and of, and in, all that was, all that is, and all that will be. It is the spiritual homeland of the awesome cosmic fundament. I know pure joy.

\section{Image Findings}

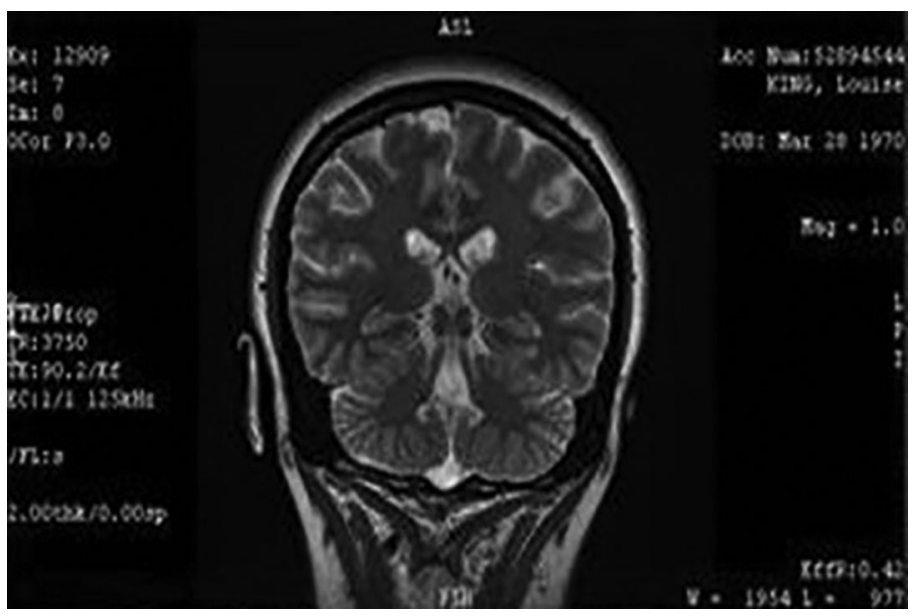

FIGURE 4. MRI scan, 30 June 2014.

Diary Entry: 25 Sept. 2014 (see Figure 4)

I am late for the appointment. The National Health Service, it seems, cannot accommodate the lateness of its service users. They make me wait two hours until the end of the clinic. Ushered in, the consultant's face makes it clear he is not in the mood to engage. Fixing my gaze, dreading his response, I tentatively ask, "What did the MRI scan show?" I am expecting some collaborative examination of impenetrable imagery. This neurologist is well respected. I want him to bring me into the world of my illness.

"The scan shows nothing," he replies. "But you have had auras. Auras are seizures, so you will need to take double the prescribed dose." I look down at my shoes, and cry. Ifeel infantilised; he has the authority, I am being told how it is. My responsibility is to comply without commotion. "What about the effects, how about my mental confusion and tiredness?" I ask. He looks up from his sheet, his brow is dark, eyebrows knotted together; he resents my intrusion into his consultation. "If you are feeling anxious, I can prescribe benzodiazepine; don't take them more than 
three days in a row." He writes a prescription; there is an arrogant flourish in his offhandedness. I feel an uncontrollable adolescent anger rising in my throat, I become indignant, feeling incensed. "What's their current black-market value?" I joke, tauntingly. The consultant responds without humour: "You cannot sell these, they are not for those who have not had them prescribed," pompously rising in his seat to claim the authority of his position. I feel belittled and look at my shoes. I drop my handbag and scrabble on the floor to collect loose items of makeup, pens, keys, bits of fluff, old train tickets. The consultant turns away and starts to speak into his Dictaphone, repeating the medical details of the conversation.

So that's it. The consultation is over. I leave the room. I am stunned. Following the signs blindly, I remember the prescription. I turn around, retrace my steps to the pharmacy, and stand waiting patiently. The pharmacist chats to a colleague about a film they have seen, handing me the tablets. I examine the sticker on the box, remember what they are, and put them straight in the bin. London roars outside, offering anonymity. Limply, I join the slipstream.

There is a power dynamic in medical encounters that can act as a catalyst for isolation and a "privatizing" experience. ${ }^{76}$ Aaron Lazare notes that patients can feel shame, humiliation, bewilderment, and insignificance, such that arriving late can seem as important as the illness itself. ${ }^{77}$

\section{Diagnosis}

I receive a copy of the letter to my General Practitioner (see Figure 5), the result of that conversation with the consultant. I have no difference in size between my hippocampi and have been prescribed an increased dosage of medication. This is not what I took away from our meeting.

\section{Diary Entry: 20 June 2019}

Presenting my inner self-standing naked before an audience. Autoethnography presents my epilepsy-but does it present me, too? It will only ever be a lens with which to view the whole-one part of a greater whole. So, in doing this, do I just reduce myself in a different way? Only, this is not a medical reduction of self to epilepsy, to broken misfiring. This is chosen. But somehow, it feels like an epilepsyfying of my inner being. This is the darkest part of me, the parts others don't have access to. And when I try to explain that there are very, very few of these experiences, that they are like precious jewels in my life that I cherish and can't share, they become frustrated. They want more, they want 
Diagnosis:

1. Temporal lobe opilepsy

Current medication:

1. Carbamazopino SR $200 \mathrm{mg}$ mano, $400 \mathrm{mg}$ nocto

Treatmont suggestion:

1. Increase Carbamaxepine slow release to $300 \mathrm{mg}$ mane and $400 \mathrm{mg}$ nocte.

2. Try Clobazam $10 \mathrm{mg}$ at times of increased stressos.

3. Consider further increases of Carbamazopine or try Lovotiracetam

\section{Current situation:}

I saw Loulso in clinic today. Recent MRI scan of her brain did not show any abnormality or asymmetry. There is some suggostion that the left hippocampus looks marginally smallor, but returns normal signal and morphology. Measuroments show no difference in the two hippocampl.

FIGURE 5. Consultant letter, 25 September 2014.

transparent access, they want to own them. But they are mine! They are precious, and fragile, and ephemeral and I have to guard them closely, in case the feeling deep down of knowing leaves me. For very good reasons, I shut them out. It is the "naked epileptic" I present. Not the whole of me, but it is the part that links me to spirituality. Well, to the cosmos, anyway.

Follow-Up

The Babylonians regarded epilepsy as a supernatural affliction and, despite Hippocrates identifying it as a physical disease, the Greek notion of a "sacred disease" persisted through the Middle Ages. ${ }^{78}$ Symptoms were understood as possession, lunacy, and mental illness, and treatment involved a combination of cauterization, trepanning, magical cures, and herbal remedies until the development of asylums, when epileptics were confined and ostracized from society. Despite the emergence of a physiological understanding of the condition, the religious connection was emphasized well into the I9 th century. ${ }^{79}$ The diagnosis of epilepsy is an important life event. ${ }^{80}$ Diagnosis is "an experience involving the deepest meanings of a person's life." 81

When I first read the list of symptoms for this syndrome, I was astounded and furious: reduced to a list of symptoms that labeled me. Screw you. I am not a list or a syndrome. Hypergraphia-an intense desire to write. No more poetry writing, then. Not that I wrote poetry for other people, but rather it was 
something I enjoyed - now it was reduced to an expression of illness. Suddenly all my choices seemed to be tainted by this list. I chose to study philosophy at university. No one could understand why. I was the first at my school to do so. It was frowned upon; the requirement was to study law, medicine, science, or languages. But philosophy? No. I was left off the list of girls going to university that year. Looking back, I now see that my choice coincided with the appearance of my epilepsy. The list, this syndrome, devalues my sense of adventure. I have always taken pride in the subject-philos (love of), sophia (knowledge). Hyposexuality - a hard subject to engage with in a public forum. This list is becoming shaming. The therapist in me questions what an acceptable level of sexuality is, rallies at the judgmentalism this implies. When I explain this at academic conferences, I make a joke of it because it is too uncomfortable to own as a reflection of myself. Perhaps it has been, but I don't own this as part of my present, reconciling my decision by reminding myself that not all of these symptoms may be experienced for a syndrome to be diagnosed. Irritability is a thorny issue for me. I have a fiery nature but keep it in my shadow - the part of myself that I struggle to express without embarrassment. Although they may have been challenging, the so-called symptoms on this list could easily be said to be my experience of my life. I may not like them, but I can see them reflected in what I thought were my choices or hobbies. The most puzzling, however, was hyperreligiosity: an intense religious experience or belief interfering with normal functioning. Well, again, I bristle at this sense of normal. I had never thought of these experiences as religious, but rather perhaps a state where my medication was not working. I ignored them, disregarding how they felt, trying to be that normal person, not affected by epilepsy. Reading the literature, I realized that other people experienced them, too, and that perhaps I could understand myself reflected in the experiences of others.

\section{Diary Entry: 25 Sept. 2014}

When I visit the neurologist for my follow-up six months later, I tell him about visiting the Tablet Room at the British Museum and show him a picture of the Sakikkū, explaining what it is. In the Sakikkū, a symptom of epilepsy is that "a man evolves his own religion." 82 He says he has only ever heard about it, never seen it. Suddenly we have a shared passion, a delight. We start to talk as equals. He is excited, wants to know about it. Emboldened by this disclosure, I guardedly mention my research into transpersonal experiences occurring during EFEs. But then something changes: He shifts in his chair and reminds me about 
people who have temporal lobe epilepsy committing violent acts-his professional persona is back and the connection we had, momentarily, is lost. I leave the follow-up feeling just as frustrated as ever. But this time it is for a different reason, because this time I saw a flash of the healer, the buman, the father, the husband -I saw that he was more complex than just a pantomime baddie. And then he deliberately put his mask back on and pushed me away-so that I was no more complex than a submissive patient.

\section{CONCLUSION}

Public perception and treatment of those with epilepsy continues to be poor, and epilepsy remains "a stigmatizing condition par excellence." ${ }^{83}$ Society has built a body of memory-pervasive across educational level, class, culture, and geography ${ }^{84}$ - that depicts those with epilepsy as dangerous, unreliable, frightening, and unable to function as adults. ${ }^{85}$ One survey of health professionals' attitudes to epilepsy resulted in responses that the researchers found to be inappropriate and ill-informed, including that 5 percent of respondents objected to a member of their family marrying someone with epilepsy. ${ }^{86}$

In light of this, it is hardly surprising that this creates a strong feeling of vulnerability and inadequacy; one woman said of her condition, "I felt less than a person." ${ }^{87}$ Individuals often avoid engagement with treatment for their symptoms because they find the prejudice more difficult to engage with than their seizures. ${ }^{88}$ This amplifies feelings of unworthiness and a selfidentity heavily influenced by societal barriers erected to limit the possibility of a conventional life, resulting in a perceived loss of social value. ${ }^{89}$ The formal and informal restriction of individuals with epilepsy supports Erving Goffman's notion of spoiled social identity. ${ }^{90}$ No surprise, then, that those with EFEs fear judgment and keep their very unusual experiences as tightly held secrets, especially when they regard themselves as not qualifying as fully human. ${ }^{91}$ As a result, they internalize the stigma, and, in a final cruel twist, anticipate it from others. ${ }^{92}$

For experients of EFEs, there is the potential for distress and rejection in encounters with healthcare professionals, as expectations differ. From the perspective of the experient, there is a desire to have their experiences met and validated, but a fear of judgment. For the medical establishment, the focus is to control seizures through a medical regimen. Individuals with epilepsy have to manage misunderstanding, as well as their symptoms, stigma, 
and shame. ${ }^{93}$ Orrin Devinsky notes that "doctors hear what they expect to hear and probe for what they expect to find." ${ }^{\prime 94}$ Patients see the encounter as highlighting defects, making them physically and psychologically vulnerable, just as doctors feel embarrassed to ask, resulting in mutual inauthenticity and a lack of compassion. ${ }^{95}$ Although narrative medicine proposes a framework for empathic engagement with patients, ${ }^{96}$ it presupposes an acceptance of illness as a type of narrative. However, it remains the case that medical professionals view epilepsy with a scientific lens, whereas their patients may have very different understandings of how epilepsy fits into the metaphysics of their worldviews. When these frameworks are not made explicit or acknowledged as being different, the causes of illness can be understood very differently. ${ }^{97}$ The patient and professional may not even realize they are starting their encounter with radically different cultural, religious, or spiritual assumptions about health and illness. As Susan Sontag explains, chronic illness necessitates citizenship of a different, dark place and all that is involved in the worldview of coming from the "kingdom of the sick." ${ }^{98}$ In the example of a young Hmong girl with epilepsy in America, the Western doctors' diagnosis was based on abnormal neural activity, whereas the girl's parents looked to an explanation grounded in perturbed ancestral spirits, encapsulating their belief system and culture; the framework that enabled them to make sense of the universe. ${ }^{99}$

In this autoethnography, I have revealed that there is a mismatch between how epilepsy is experienced and how medical professionals regard it, and that there is a need for the medical establishment to take seriously the experiences of the people they meet with in their clinics. I suggest that rather than capturing numbers that aid diagnosis, methods intended to research EFEs need to capture their phenomenology and consider the meanings they have for experients. Autoethnography has been presented as an evocative approach that honors this phenomenology. I argue that it is a valuable method for expressing these rich, complex, controversial, or disputed experiences because it rejects reductionism and explores human experience from an embodied perspective. In using autoethnography, I have problematized current medical responses to EFEs and shown how seeing them as symptomatic of psychosis both reinforces antiquated stereotypes of individuals with epilepsy as "mad" and ignores how they can contribute to a profound sense of well-being. Being human lies not in the neurotypical, but in difference. Medical professionals need to be aware of this when dealing with patients who have temporal lobe epilepsy and question their views of EFEs as inauthentic. By considering the emotional responses EFEs raise in their own worldviews, medical 
professionals may develop, as Charon proposes, more empathy and understanding of their patients. ${ }^{100}$ Autoethnography enables a critical mirror to be held up to the views of self and culture, and as Arthur W. Frank says, in doing so holds the voices of many-not just the researcher. ${ }^{101}$

In this autoethnography, I have illustrated the experience of living with temporal lobe epilepsy and how, through researching the experiences of others, I have come to understand my own experiences as spiritual. I have opened a window into EFEs-experiences of a non-shared reality, the phenomenology of which is absent from medical literature. I understand my EFEs to be spiritual because they include experiences that are regarded as mystical. That is, an out-of-body experience of the order of creation, and the EFE with my therapist, where I connected with the unity of consciousness. This transformation allowed me to integrate the authority of my own experiences, and to accept my experiences as spiritual without the judgment of others. My epiphany is that through having epilepsy, I have access to a spirituality that encompasses alternate realities. In my narratives, I have created a space for this epiphany to be not only personally, but also societally, transformative. For Charon, this telling may create the opportunity to consider a shared humanity by being differently positioned to the experience. ${ }^{102}$ By understanding EFEs, we can embrace them as a new way to understand the embodied human experience.

\section{ACKNOWLEDGEMENTS}

I gratefully acknowledge the kind encouragement, critical commentary, and guidance provided by Chris Roe, Liz Roxburgh, Melinda Spencer, and Nigel Hamilton. I thank my parents for their unconditional love in navigating my relationship with epilepsy. I would also like to thank the reviewers for their valuable suggestions and for helping me to truly find and own my autoethnographic voice.

LoUISE SpIers is an Integrative Transpersonal Psychotherapist and Counsellor. She has a private psychotherapy practice in London, where she uses creative therapeutic methods that include the use of dreams and archetypal symbolism to facilitate healing in adult clients. She is also a Senior Lecturer in Psychology \& Counselling at the University of Northampton, where she is a doctoral candidate conducting research into transpersonal understandings of spiritual experiences in epilepsy. Louise is passionate about the power of autoethnography as a qualitative methodology for researching the phenomenology of experiences that are otherwise pathologized or silenced. Correspondence to: Louise Spiers, Department of Psychology, Faculty of Health, Education and Society, Waterside Campus, The University of Northampton, University Drive, Northampton NNI 5 HP, UK. Email: Louise.Spiers@northampton.ac.uk. 


\section{NOTES}

I. William Shakespeare: The Complete Works (New York: Barnes \& Noble, 1994).

2. Bjørn Åsheim Hansen and Eylert Brodtkorb, "Partial Epilepsy with 'Ecstatic' Seizures," Epilepsy \& Behavior 4, no. 6 (2003): 667-73.

3. Alexander Moreira-Almeida et al., "WPA Position Statement on Spirituality and Religion in Psychiatry," World Psychiatry I5, no. I (2016): 87-88.

4. Rita Charon, Narrative Medicine: Honoring the Stories of Illness (Oxford: Oxford University Press, 2008).

5. Hanna Admi and Beatrice Shaham, "Living with Epilepsy: Ordinary People Coping with Extraordinary Situations," Qualitative Health Research I7 no. 9 (2007): II78-87.

6. Edward H. Reynolds, “The ILAE/IBE/WHO Epilepsy Global Campaign History," Epilepsia 43, Suppl. 6 (2002): 9-II.

7. Robert S. Fisher et al., "ILAE Official Report: A Practical Clinical Definition of Epilepsy," Epilepsia 55, no. 4 (2002): 475-82.

8. NINDS, The Epilepsies and Seizures: Hope through Research, National Institute of Neurological Disorders and Stroke (Bethesda, MD: National Institutes of Health, 2016); Peter Fenwick and Elizabeth Fenwick, Living with Epilepsy. A Guide to Taking Control (London: Bloomsbury, 1996); Robert S. Fisher et al., "Epileptic Seizures and Epilepsy: Definitions Proposed by the International League Against Epilepsy (ILAE) and the International Bureau for Epilepsy (IBE)," Epilepsia 46, no. 4 (2005): 470-72.

9. Robert Kloster and Torstein Engelskjøn, "Sudden Unexpected Death in Epilepsy (SUDEP): A Clinical Perspective and a Search for Risk Factors," Journal of Neurology, Neurosurgery \& Psychiatry 67, no. 4 (1999): 439-44.

Io. Rajendra Kale, "Bringing Epilepsy Out of the Shadows," BMJ: British Medical Journal 315, no. 7099 (1997): 2.

II. Gus A. Baker et al., "Quality of Life of People with Epilepsy: A European Study," Epilepsia 38, no. 3 (1997): 353.

I2. World Health Organization, Epilepsy Factsheet, 2017, updated February 2017, http://www.who.int/mediacentre/factsheets/fs999/en/.

I3. Fenwick and Fenwick, Living with Epilepsy.

I4. Åsheim Hansen and Brodtkorb, "Partial Epilepsy with 'Ecstatic' Seizures."

15. Fenwick and Fenwick, Living with Epilepsy.

I6. Rima Dolgoff-Kaspar et al., "Numinous-Like Auras and Spirituality in Persons with Partial Seizures," Epilepsia 52, no. 3 (2011): 640-44.

I7. See, respectively, Fabienne Picard and Andrew D. Craig, "Ecstatic Epileptic Seizures: A Potential Window on the Neural Basis for Human Self-Awareness," Epilepsy \& Behavior I6, no. 3 (2009): 539-46; Oliver Sacks, Hallucinations (London: Picador, 2012). Vernon M. Neppe, "Models of the Out-of-Body Experience: A New Multi-Etiological Phenomenological Approach,” NeuroQuantology 9, no. I (20II): 72-83; John Palmer and Vernon M. Neppe, "A Controlled Analysis of Subjective Paranormal Experiences in Temporal Lobe Dysfunction in a Neuropsychiatric Population," Journal of Parapsychology 67, no. I (2003): 75-97; Michael A. Persinger, 
"The Neuropsychiatry of Paranormal Experiences," Journal of Neuropsychiatry and Clinical Neurosciences I3, no. 4 (2001): 515-24; V. S. Ramachandran and Sandra Blakeslee, "God and the Limbic System," in Phantoms in the Brain: Probing the Mysteries of the Human Mind (New York: Quill, I999), I74-198; Dolgoff-Kaspar et al., "Numinous-Like Auras and Spirituality and Spirituality in Persons with Partial Seizures"; Åsheim Hansen and Brodtkorb, "Partial Epilepsy with 'Ecstatic' Seizures."

I8. Kenneth Dewhurst and A. W. Beard, "Sudden Religious Conversions in Temporal Lobe Epilepsy," Epilepsy \& Behavior 4, no. I (2003): 78-87.

19. Picard and Craig, "Ecstatic Epileptic Seizures."

20. Fyodor Dostoevsky, cited in Théophile Alajouanine, "Dostoiewski's Epilepsy," Brain 86, no. 2 (1963): 209-18.

2I. Ahmed Gaber, "Semiological Bridge between Psychiatry and Epilepsy," Journal of Psychology and Clinical Psychiatry 8, no. I, 00467 (2017): I-7, https://medcraveonline. com/JPCPY/JPCPY-o8-00467.pdf.

22. William Braud, "Health and Well-Being Benefits of Exceptional Human Experience," in Mental Health and Anomalous Experience, ed. Craig D. Murray (New York: Nova Science Publishers, 2012), I07-24; Etzel Cardeña, John Palmer, and David Marcusson-Clavertz, eds., Parapsychology: A Handbook for the 2Ist Century (Jefferson, NC: McFarland \& Company, 2015).

23. Renaud Evraud, "Clinical Psychology of Anomalous Experiences: Roots and Paradigms," in Mental Health and Anomalous Experience, ed. Craig D. Murray (New York: Nova Science Publishers, 2012), 89-106.

24. Burkhard S. Kasper, Ekkehard M. Kasper, E. Pauli, and Holban Stefan, "Phenomenology of Hallucinations, Illusions, and Delusions as Part of Seizure Semiology," Epilepsy \& Behavior I8, no. I (2010): I3-23; Wilder Penfield and Herbert Jasper, Epilepsy and the Functional Anatomy of the Human Brain (Boston: Little, Brown and Company, 1954).

25. Laura Veronelli et al., "Geschwind Syndrome in Frontotemporal Lobar Degeneration: Neuroanatomical and Neuropsychological Features over 9 Years," Cortex 94 (2017): $27-38$.

26. Michael Trimble and Anthony Freeman, "An Investigation of Religiosity and the Gastaut-Geschwind Syndrome in Patients with Temporal Lobe Epilepsy," Epilepsy \& Behavior 9, no. 3 (2006): 407-I4.

27. William James, The Varieties of Religious Experience: A Study in Human Nature (New York: Longmans, Green, 1902).

28. Peter Fenwick, "The Neurophysiology of Religious Experiences," in Psychiatry and Religion: Context, Consensus and Controversies, ed. Dinesh Bhugra (London: Routledge, I997), I67-77.

29. Jacob Kaminker and David Lukoff, "Transpersonal Perspectives on Mental Health and Mental Illness," in The Wiley-Blackwell Handbook of Transpersonal Psychology, ed. Harris L. Friedman and Glenn Hartelius (Malden, MA: Wiley-Blackwell, 2013), 419-32.

30. Anne Fadiman, The Spirit Catches You and You Fall Down: A Hmong Child, Her American Doctors, and the Collision of Two Cultures (New York: Farrar, Straus and 
Giroux, 2012); Owsei Temkin, The Falling Sickness: A History of Epilepsy from the Greeks to the Beginnings of Modern Neurology, 2nd ed. (Baltimore, MD: Johns Hopkins University Press, 1994).

3I. Sacks, Hallucinations.

32. See Nigel P. Short, Lydia Turner, and Alec Grant, eds., Contemporary British Autoethnography (Rotterdam, Netherlands: Sense, 2013); Margaret Chapman-Clarke, "'Discovering' Autoethnography as a Research Genre, Methodology and Method: 'The Yin and Yang of Life," Transpersonal Psychology Review I8, no. 2 (2016): Io-I8; Diana Raab, "Transpersonal Approaches to Autoethnographic Research and Writing," The Qualitative Report I8, no. 4I (2013): I-I9.

33. Nigel P. Short, "An Englishman Abroad: An Autoethnographic Tale," in Contemporary British Autoethnography, ed. Nigel P. Short, Lydia Turner, and Alec Grant (Rotterdam, Netherlands: Sense, 2013), 97-I26; Arthur W. Frank, The Wounded Storyteller: Body, Illness, and Ethics (Chicago: University of Chicago Press, 1995); Elizabeth Ettore, "Gender, Older Female Bodies and Autoethnography: Finding My Feminist Voice by Telling My Illness Story," Women's Studies International Forum 28, no. 6 (2005): 535-46; Rita Marcalo, "Involuntary Dances," Research Ethics 8, no. I (2012): 57-59; Sarah V. Scarfe and Caroline Marlow, "Overcoming the Fear: An Autoethnographic Narrative of Running with Epilepsy," Qualitative Research in Sport, Exercise and Health 7, no. 5 (2015): 688-97.

34. Carolyn Ellis and Arthur P. Bochner, "Autoethnography, Personal Narrative, Reflexivity: Researcher as Subject," in Handbook of Qualitative Research, 2nd ed., ed. Norman K. Denzin and Yvonna S. Lincoln (Thousand Oaks, CA: Sage, 200o), 733-68; Heewon Chang, "Autoethnography in Health Research: Growing Pains?" Qualitative Health Research 26, no. 4 (2016): 443-51.

35. Carolyn Ellis, The Ethnographic I: A Methodological Novel about Autoethnography (New York: AltaMira Press, 2004).

36. David Hockney, cited in Chris Stephens and Andrew Wilson, David Hockney (London: Tate Publishing, 2017).

37. Short, "An Englishman Abroad."

38. Ruth Behar, The Vulnerable Observer: Anthropology That Breaks Your Heart (Boston: Beacon Press, 1996).

39. Ethical approval for this autoethnographic study was awarded by the University of Northampton Research Ethics Committee.

40. Martin Tolich, "A Critique of Current Practice: Ten Foundational Guidelines for Autoethnographers," Qualitative Health Research 20, no. I2 (2010): I599-6ro.

4I. Colleen Tenni, Anne Smyth, and Carlene Boucher, "The Researcher as Autobiographer: Analysing Data Written about Oneself," The Qualitative Report 8, no. I (2003): I-I2.

42. Charlotte Aull Davies, Reflexive Ethnography: A Guide to Researching Selves and Others (London: Routledge, 2007).

43. Deborah E. Danahay-Reed, Auto/ethnography: Rewriting the Self and the Social (New York: Berg, I997). 
44. Davies, Reflexive Ethnography.

45. Frank, The Wounded Storyteller; Andrew C. Sparkes, "The Fatal Flaw: A Narrative of the Fragile Body-Self," Qualitative Inquiry 2, no. 4 (1996): 46394 .

46. Carolyn Ellis, "Creating Criteria: An Ethnographic Short Story," Qualitative Inquiry 6, no. 2 (2000): 273-77.

47. Hermann Stefan, Elinor Ben-Menachem, Patrick Chauvel, and Renzo Guerrini, eds., Case Studies in Epilepsy: Common and Uncommon Presentations (Cambridge: Cambridge University Press, 2012).

48. Elizabeth F. Hobdell et al., "Chronic Sorrow and Coping in Families of Children with Epilepsy," Journal of Neuroscience Nursing 39, no. 2 (2007): 76-82.

49. Hansard HC Deb vol. I25 cols. I228-I96I. 22 January I988. Retrieved on I 8 August 2018 from https://api.parliament.uk/historichansard/commons/I988/jan/22/ abortion-amendment-bill-I\#S6CVoI25Po_19880I22_HOC_34.

50. Fenwick and Fenwick, Living with Epilepsy.

5I. Chumbawamba, "Smash Clause 28! Fight the Alton Bill" (Castleford, UK: Agit Prop Records, I988), Single.

52. Penny Rhodes, Andrew Nocon, Neil Small, and John Wright, "Disability and Identity: The Challenge of Epilepsy," Disability \& Society 23, no. 4 (2008): 385-95.

53. Admi and Shaham, "Living with Epilepsy."

54. Joseph W. Schneider and Peter Conrad, Having Epilepsy: The Experience and Control of Illness (Philadelphia, PA: Temple University Press, 1983).

55. Malcolm Hayden, Carolyn Penna, and Neil Buchanan, "Epilepsy: Patient Perceptions of Their Condition," Seizure I, no. 3 (I992): I9I-97.

56. Steven C. Schachter, Kaarkuzhali Babu Krishnamurthy, and Deborah T. Combs-Cantrell, Epilepsy in Our Lives: Women Living with Epilepsy (Oxford: Oxford University Press, 2008), 3.

57. Åsheim Hansen and Brodtkorb, "Partial Epilepsy with 'Ecstatic' Seizures." For example, patient I explains these as sensations that are a "trance of pleasure" (668) and patient Io calls them "pleasant and joyous" (670).

58. Schachter, Krishnamurthy, and Cantrell, Epilepsy in Our Lives. One woman said, "It is such a different place it is beyond reality" (77).

59. Åsheim Hansen and Brodtkorb, "Partial Epilepsy with 'Ecstatic' Seizures."

6o. Picard and Craig, "Ecstatic Epileptic Seizures," 540.

6I. Elizabeth Barrett Browning, Aurora Leigh, lines 21-23, in The Oxford Book of English Mystical Verse 19I7, ed. D. H. S. Nicholson and A. H. E. Lee (New York: Bartleby.com, 2000).

62. Vernon M. Neppe, "Temporal Lobe Symptomatology in Subjective Paranormal Experiments," Journal of the American Society for Psychical Research 77, no. I (1983): I-29; Michael A. Persinger and Katherine Makarec, "Complex Partial Epileptic Signs as a Continuum from Normals to Epileptics: Normative Data and Clinical Populations," Journal of Clinical Psychology 49, no. I (I993): 33-45.

63. Braud, "Health and Well-Being Benefits of Exceptional Human Experience," Io7. 
64. Roger N. Walsh and Frances Vaughan, eds., Beyond Ego: Transpersonal Dimensions in Psychology (Los Angeles: J. P. Tarcher, I980); Mike Michael, "A Paradigm Shift? Connections with Other Critiques of Social Constructionism," in Social Constructionist Psychology: A Critical Analysis of Theory and Practice, ed. David J. Nightingale and John Cromby (Buckingham, UK: Open University Press, 1999), 53 .

65. Elizabeth C. Roxburgh and Rachel E. Evenden, "Most People Think You're a Fruit Loop': Clients' Experiences of Seeking Support for Anomalous Experiences," Counselling and Psychotherapy Research I6, no. 3 (2016): 2II-2I.

66. Åsheim Hansen and Brodtkorb, "Partial Epilepsy with 'Ecstatic' Seizures."

67. J. Hughlings Jackson and Walter S. Colman, "Case of Epilepsy with Tasting Movements and 'Dreamy State'-Very Small Patch of Softening in the Left Uncinate Gyrus," Brain 2I, no. 4 (I898): 580-90. When discussing epileptic "dreamy states," these prominent epileptologists dismiss patient experiences as completely unrelated to neuronal firings of the brain.

68. Janine Goldstein, Michael Seidenberg, and Rolf Peterson, "Fear of Seizures and Behavioral Functioning in Adults with Epilepsy," Journal of Epilepsy 3, no. 2 (1990): IOI-IO6.

69. DSM V Codes 293.8I and 293.82: Psychotic Disorder Due to a General Medical Condition (Diagnostic and Statistical Manual of Mental Disorders, 5th ed. [Washington, DC: American Psychiatric Association, 2013]). This is used for differential diagnosis and extensively within the literature. See, for example Gaber, "Semiological Bridge between Psychiatry and Epilepsy."

70. Robin Wooffitt, Telling Tales of the Unexpected: The Organization of Factual Discourse (Lanham, MD: Rowman \& Littlefield, I992).

71. See, for example Caroline Brett, Charles Heriot-Maitland, Philip McGuire, and Emmanuelle Peters, "Predictors of Distress Associated with Psychotic-like Anomalous Experiences in Clinical and Non-clinical Populations," British Journal of Clinical Psychology 53, no. 2 (2014): 213-27.

72. Ann Jacoby, Dee Snape, and Gus A. Baker, "Epilepsy and Social Identity: The Stigma of a Chronic Neurological Disorder," The Lancet Neurology 4, no. 3 (2005): I $7 \mathrm{I}-78$.

73. Charon, Narrative Medicine.

74. Ian James Kidd and Havi Carel, "Epistemic Injustice and Illness," Journal of Applied Philosophy 34, no. 2 (2017): 172-90.

75. Havi Carel, Illness: The Cry of the Flesh (London: Routledge, 2018).

76. Charon, Narrative Medicine; Joseph W. Schneider, Having Epilepsy: The Experience and Control of Illness (Philadelphia, PA: Temple University Press, 2009).

77. Aaron Lazare, "Shame and Humiliation in the Medical Encounter," Archives of Internal Medicine I47, no. 9 (1987): 1653-58.

78. J. V. Wilson and E. H. Reynolds, "Translation and Analysis of a Cuneiform Text Forming Part of a Babylonian Treatise on Epilepsy," Medical History 34, no. 2 (1990): I85; Temkin, The Falling Sickness. 
79. Orrin Devinsky and George Lai, "Spirituality and Religion in Epilepsy," Epilepsy \& Behavior I2, no. 4 (2008): 636-43; Temkin, The Falling Sickness.

8o. Joseph W. Schneider and Peter Conrad, "In the Closet with Illness: Epilepsy, Stigma Potential and Information Control," Social Problems 28, no. I (I980): $32-44$.

81. Steven C. Schachter, Epilepsy in Our Words: Personal Accounts of Living with Seizures (Oxford: Oxford University Press, 2008), xiv.

82. Edward H. Reynolds and James V. Kinnier Wilson, "Psychoses of Epilepsy in Babylon: The Oldest Account of the Disorder," Epilepsia 49, no. 9 (2008): 26 I6.

83. Baker et al., "Quality of Life of People with Epilepsy," 353.

84. Research supports similar cross-cultural attitudes across socioeconomic groups in Korea, Brazil, and Nigeria. See, for example Ming-Yao Chung, Yang-chyuan Chang, Yen-Huei C. Lai, and Chi-Wan Lai, "Survey of Public Awareness, Understanding, and Attitudes toward Epilepsy in Taiwan,” Epilepsia 36, no. 5 (1995): 488-93; Isabel C. Santos et al., "Public Awareness and Attitudes toward Epilepsy in Different Social Segments in Brazil," Arquivos de Neuro-Psiquiatriac 56, no. I (1998):32-38; Emmanuel O. Sanya et al., "Perception and Attitude to Epilepsy among Teachers in Primary, Secondary and Tertiary Educational Institutions in Middle Belt Nigeria," Tropical Doctor 35, no. 3 (2005): 153-56.

85. Schneider and Conrad, "In the Closet with Illness."

86. Cecilia E. Aragon, Tiiu Hess, and Jorge G. Burneo, "Knowledge and Attitudes about Epilepsy: A Survey of Dentists in London, Ontario," Journal of the Canadian Dental Association 75, no. 6 (2009): 450a-g.

87. Schachter, Krishnamurthy, and Cantrell, Epilepsy in Our Lives, 2.

88. World Health Organization, Epilepsy Factsheet.

89. Schneider and Conrad, Having Epilepsy; Jacoby, Snape, and Baker, "Epilepsy and Social Identity."

9o. Erving Goffman, Stigma: Notes on the Management of Spoiled Identity (Englewood Cliffs, NJ: Prentice-Hall, 1963).

91. Goffman, Stigma.

92. Gloria Joachim and Sonia Acorn, "Stigma of Visible and Invisible Chronic Conditions," Journal of Advanced Nursing 32, no. I (200o): 243-48.

93. Graham Scambler and Anthony Hopkins, "Being Epileptic: Coming to Terms with Stigma," Sociology of Health \& Illness 8 (1986): 26-43.

94. Orrin Devinsky, foreword to Epilepsy in Our Words: Personal Accounts of Living with Seizures, by Steven C. Schachter (Oxford: Oxford University Press, 2008), xii.

95. Lazare, "Shame and Humiliation in the Medical Encounter"; Charon, Narrative Medicine.

96. Charon, Narrative Medicine.

97. Charon, Narrative Medicine.

98. Susan Sontag, Illness as Metaphor (New York: Farrar, Straus and Giroux, 1978), 3.

99. Fadiman, The Spirit Catches You and You Fall Down.

Ioo. Charon, Narrative Medicine. 
IOI. Lisa R. Merriweather, "Autoethnography as Counternarrative: Confronting Myths in the Academy-An African American Female Perspective," in Autoethnography as a Lighthouse: Illuminating Race, Research, and the Politics of Schooling, ed. Stephen D. Hancock, Ayana Allen, and Chance W. Lewis (Charlotte, NC: Information Age Publishing, 2015), 47-66; Frank, The Wounded Storyteller.

I02. Charon, Narrative Medicine. 